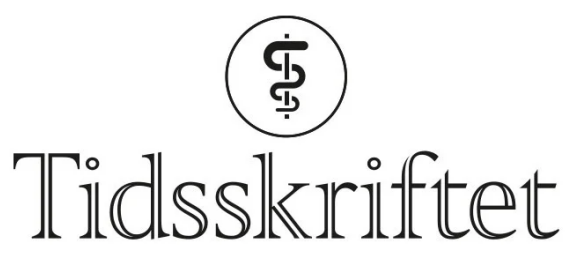

DEN NORSKE LEGEFORENING

\title{
Ganske vanlig, men uforsvarlig
}

BREV TIL REDAKTØREN

DAG KRISTEN SOLBERG

ESPEN MOLDEN

HELGE REFSUM

Diakonhjemmet Sykehus

Klopidogrel (Plavix) er blant de 5-7\% av legemidlene som klassifiseres som prodrugs. Felles for disse er at legemiddelmolekylene må gjennomgå en kjemisk omdanning i kroppen for å bli farmakologisk aktive. Enzymer innen cytokrom P-450 (CYP)-familien er sentrale i omsetningen av legemidler som brukes i behandlingen av en rekke lidelser, herunder hjerte- og karlidelser, kreft, psykiske og nevrologiske lidelser. CYP-enzymene utviser store individuelle forskjeller i fenotype, relatert til genetiske forhold, sykdomstilstander eller miljøpåvirkning. Medfødte mutasjoner gjør at om lag 10\% av befolkningen i Norge har betydelig redusert funksjon av ett eller flere CYP-enzymer. Dette medfører risiko for terapisvikt ved behandling med prodrugs.

I to nylig publiserte artikler er det vist at effekten av behandling med klopidogrel er knyttet til CYP-funksjon $(\underline{1}, \underline{2})$. Klopidogrel gis som prodrug og omdannes til aktivt virkestoff av $\mathrm{CYP}_{2} \mathrm{C}_{19}$. Artiklene i The Lancet og New England Journal of Medicine viste at risikoen for terapisvikt, dvs. nye kardiovaskulære hendelser og død, var betydelig økt for pasienter med nedsatt funksjon i CYP2C19. I 2007 brukte mer enn 23000 norske pasienter klopidogrel, og legemidlet ble omsatt for 95 millioner kroner (3).3-5\% av befolkningen er homozygote for gener som gir betydelig nedsatt funksjon i CYP2C19, ytterligere $30 \%$ er bærere av ett gen og har noe nedsatt funksjon. Det finnes ingen surrogatmarkør for å vurdere hvem som har forebyggende effekt av klopidogrel. Behandling med dette legemidlet uten genotyping av $\mathrm{CYP}_{2} \mathrm{C}_{19}$ gir terapisvikt med svært alvorlige konsekvenser for enkeltpasienter og $ø$ kte kostnader for helsevesenet.

Genetisk variasjon i CYP-enzymer er vist å predikere dosebehov av en rekke legemidler. Allikevel er genotyping lite brukt og tilsynelatende fortsatt kontroversielt innen somatisk medisin. Det er en utbredt holdning at effekten av genotyping ikke er dokumentert, verken medisinsk eller økonomisk (4,5). Når det gjelder klopidogrel, er det vanskelig å se at dokumentasjonsgrunnlaget kan bli bedre. Dersom de omtalte artiklene ikke godt nok dokumenterer nytten av genotyping ved behandling med klopidogrel, ønsker vi å stille spørsmål ved hvilken dokumentasjon som kreves. 
Prøve-og-feile-tilnærming er vanlig. Dersom et legemiddel ikke virker, kan et nytt prøves. Imidlertid finnes det alternativer til denne fremgangsmåten. CYP-genotyping kan identifisere pasienter med risiko for terapisvikt og bivirkninger, samt bidra til å redusere legemiddelkostnader. CYP-genotyping er tilgjengelig ved laboratorier i alle helseregioner. Hvorvidt prøve-og-feile-tilnærmingen også er uforsvarlig, bør bli gjenstand for både debatt og forskning.

\section{LITTERATUR}

1. Collet JP, Hulot JS, Pena A et al. Cytochrome $\mathrm{P} 4502 \mathrm{O} 19$ polymorphism in young patients treated with clopidogrel after myocardial infarction: a cohort study. Lancet 2009; 373:309-17.

2. Simon T, Verstuyft C, Mary-Krause M et al. Genetic determinants of response to clopidogrel and cardiovascular events. N Engl J Med 2009;360:363-75.

3. Reseptregisteret. Oslo: Folkehelseinstituttet, 2009. www.reseptregisteret.no (24.3.2009).

4. Nilsen L. Dårlig respons på Plavix. Dagens Medisin 29.1.2009.

www.dagensmedisin.no/nyheter/2009/01/29/darlig-respons-pa-plavix/index.xml (24.3.2009).

5. Storey RF. Clopidogrel in acute coronary syndrome: to genotype or not? Lancet 2009;373: 276-8.

Publisert:30. april 2009. Tidsskr Nor Legeforen. DOI: 10.4045/tidsskr.09.0332

(C) Tidsskrift for Den norske legeforening 2023. Lastet ned fra tidsskriftet.no 26. april 2023. 